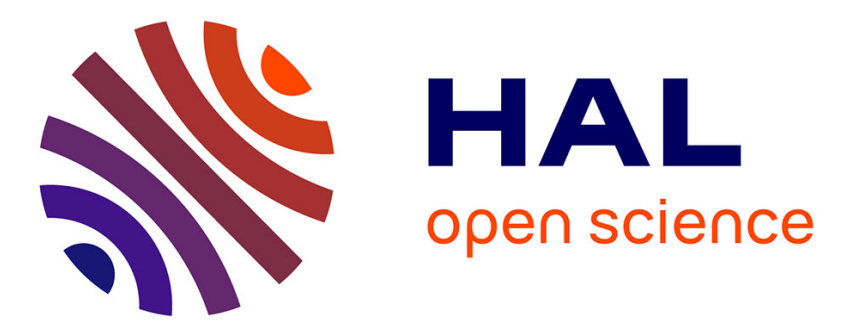

\title{
Role of glycosidic aroma precursors on the odorant profiles of Grenache noir and Syrah wines from the Rhone valley. Part 2: characterisation of derived compounds
}

Marie Segurel, Raymond Baumes, Dominique Langlois, C. Riou, Jean Razungles

\section{To cite this version:}

Marie Segurel, Raymond Baumes, Dominique Langlois, C. Riou, Jean Razungles. Role of glycosidic aroma precursors on the odorant profiles of Grenache noir and Syrah wines from the Rhone valley. Part 2: characterisation of derived compounds. Journal International des Sciences de la Vigne et du Vin, 2009, 43 (4), pp.213-223. 10.20870/oeno-one.2009.43.4.794 . hal-02655497

\section{HAL Id: hal-02655497 \\ https://hal.inrae.fr/hal-02655497}

Submitted on 29 May 2020

HAL is a multi-disciplinary open access archive for the deposit and dissemination of scientific research documents, whether they are published or not. The documents may come from teaching and research institutions in France or abroad, or from public or private research centers.
L'archive ouverte pluridisciplinaire HAL, est destinée au dépôt et à la diffusion de documents scientifiques de niveau recherche, publiés ou non, émanant des établissements d'enseignement et de recherche français ou étrangers, des laboratoires publics ou privés.

$$
\text { Copyright }
$$




\section{www.jisvv.com}

\section{Journal}

\section{International}

\section{des Sciences}

de la Vigne

et du Vin

Volume 43 [2009] Number 4 


\title{
ROLE OF GLYCOSIDIC AROMA PRECURSORS ON THE ODORANT PROFILES OF GRENACHE NOIR AND SYRAH WINES FROM THE RHONE VALLEY. PART 2: CHARACTERISATION OF DERIVED COMPOUNDS
}

\author{
Marie A. SEGUREL ${ }^{\dagger 1,2}$, R. L. BAUMES ${ }^{1}$, D. LANGLOIS ${ }^{3}$, \\ Ch. RIOU ${ }^{2}$ and A. J. RAZUNGLES $1, *$ \\ 1: INRA, UMR SPO, 2 place Viala, 34060 Montpellier cedex 1, France. \\ 2: INTER-RHONE, Interprofession des vins AOC Côtes-du-Rhône et Vallée du Rhône, \\ 2260 route du Grès, 84100 Orange, France \\ 3: INRA, UMR Flavic, BP 86510, 17 rue Sully, 21065 Dijon, France
}

\begin{abstract}
Aims: Grenache noir and Syrah are the predominant grape varieties in the French Rhone valley vineyard. This study aimed at identifying the odorants generated from glycoconjugates extracted from wines made with Grenache noir and Syrah.

Methods and results: Synthetic model wines enriched with glycoconjugates, treated or not with enzymes, were stored at $45^{\circ} \mathrm{C}$ for 3 weeks, or at $13^{\circ} \mathrm{C}$ for 18 months. Aromas generated were extracted and analyzed by GC-Olfactometry (only samples from accelerated aging) and were further quantitatively determined by GC-MS. Analysis of the extracts allowed to identify 49 odorants, including 27 that could be aglycons, or related compounds, of glycoconjugates from the grapes. In addition, the active compounds were quantified in similar experiments led in conditions of natural aging for 18 months.
\end{abstract}

Conclusion: The two varieties, Grenache noir and Syrah, were distinguishable by 14 odorant zones. Multivariate analyses (PCA) performed with the amounts of aroma compounds formed during both model and natural aging confirmed the effect of the glycosidase treatment on the acceleration of the aroma compounds formation and on the increase of the varietal differences of the wines.

Significance and impact of study: GC-Olfactometry coupled with GCMS were good techniques to indentify and apreciate the odorants generated from glycoconjugates in the wines of Syrah and Grenache Noir, but in the context of a blend of odors, these techniques showed their limits and did not permit to determine the real impact of a molecule in the global aroma of the wine perceived by the taster. Other methods as additive techniques should be used to complete this study.

Keywords: Aging, aroma precursors, glycoconjugates, Grenache noir, olfactometry, Syrah, wine

\begin{abstract}
Résumé
Objectif : Le Grenache noir et la Syrah sont les cépages les plus utilisés en vallée du Rhône. L'objectif de cette étude était de caractériser les composés odorants, issus des glycosides du raisin, susceptibles d'intervenir dans le profil olfactif des vins de ces deux variétés. Pour y parvenir, des solutions modèles de vins enrichies en précurseurs glycosylés, provenant de raisins de Grenache et de Syrah, ont été utilisées.
\end{abstract}

Méthodes et résultats : Les solutions modèles de vin enrichies ont été soumises à un vieillissement artificiel accéléré. Les aglycones formées ont été analysées par CPG-olfactométrie. L'analyse des extraits par CPG-SM a permis d'identifier 49 composés odorants, dont 27 pourraient être des aglycones ou des composés dérivant d'aglycones provenant des glycosides du raisin. De plus, ces composés odorants ont été quantifiés sur ces solutions modèles vieillies de façon accélérée, et sur les mêmes solutions soumises à un élevage naturel de 18 mois.

Conclusions : Les deux variétés, Grenache noir et Syrah, se sont différenciées par 14 zones odorantes. Des analyses multivariées (ACP), réalisées en utilisant les teneurs en composés obtenues par les deux vieillissements artificiel et naturel, ont confirmé l'influence du traitement par des glycosidases sur l'accélération de la formation des composés odorants issus des glycosides et sur l'amplification de la différence variétale entre les vins.

Signification et impact de l'étude : La CPG couplée à l'olfactométrie et à la spectrométrie de masse permet d'apprécier le caractère odorant d'un composé volatil dans l'extrait analysé et son implication possible dans l'arôme du vin. Cette étude a permis de déterminer les principaux composés odorants provenant des glycosides des baies de Grenache noir et de Syrah. Cependant dans le contexte d'un mélange d'odeurs, ces techniques ont montré leurs limites et n'ont pas permis de démontrer l'effet d'un composé sur l'arôme global du vin, tel que perçu par le dégustateur. D'autre méthodes comme les techniques additives pourraient être utilisées pour compléter cette étude.

Mots clés : élevage, précurseurs d'arômes, glycosides, Grenache noir, olfactométrie, Syrah, vin 


\section{INTRODUCTION}

Except for a few aromatic varieties, the berries from most Vitis vinifera varieties have no specific odors. Yet, some of these so called neutral varieties, such as Grenache noir and Syrah yield wines with an aroma specific of the variety. Such specific olfactive notes were attributed mainly to odorants generated from non odorous precursors occurring in grape berries. Among them are the glycoconjugates which make up an important reserve of aroma, and contributes to the aroma complexity acquired by the wines during aging. Grape glycoconjugates are composed of a sugar moiety, including always a glucose bound to a volatile aglycone by $\beta$-glucosidic bond. Glycosides can be hydrolysed enzymatically and/or chemically (Marais, 1983; Winterhalter, 1993) to release the volatile aglycons which can eventually undergo structural modification. The mild conditions used generally in enzymatic hydrolysis do not alter the structure of the aglycons (Gunata et al., 1985, Winterhalter and Skouroumounis, 1997) which can be analyzed by GCMS. On the contrary, acid catalyzed hydrolysis favours structural transformations of the aglycons such as those observed during wine aging (Sefton et al., 1993). The GC-Olfactometry (GC-O) was used to identify odorant zones and the compounds potentially responsible for the Grenache wine aroma (Ferreira et al., 2002; Lopez et al., 2004).

Several GC-O methods were suited for the identification and ranking attending to potential importance of odorants from complex products. They were grouped in two categories:

- Methods of successive dilutions, AEDA (Aroma Extract Dilution Analysis; (Acree et al., 1984)) and CHARM (Combined Hedonic Response Measurement; (Ullrich and Grosch, 1987)).

- Methods based on the analysis of an extract with one single concentration as the detection frequency method. In this method developed more recently (Van Ruth et al., 1996, Pollien et al., 1997), the measured variable was the detection frequency of odours by the whole panel. In this case, there was a good correlation between the intensity of the odour and the detection frequency of this same odour.

Strickly speaking, these methods include two different types of strategies, the detection frequency based methods and the posterior intensity measurement methods. The comparison of the advantages and drawbacks of these different methods (Van Ruth, 2001) revealed that methods based on the analysis of an extract with one single concentration are the most reproducible and best adapted to measuring the olfactory intensity because they take into account the Stevens law which relates the odour intensity to the concentration of the odorant. Moreover, contrary to the dilution techniques, they offered the possibility of validate statistically the results, and need less analyses. This method was used in this study.

In a previous paper (Ségurel et al., 2009), we demonstrated that the olfactory profiles of Syrah and Grenache noir wines were different and that the odorants resulting from glycosidic precursors played a significant role in this difference. These results confirmed those previously obtained with wines of the two varieties Grenache and Syrah (Abbot et al., 1991; Ormieres et al., 1997; Ferreira et al., 1998; Lopez et al., 1999, Ferreira et al., 2002; Lopez et al., 2004). In this paper, the aim was to identify the aroma compounds resulting from grape glycosides implicated in the aroma expression of these varietal wines. The addition of glycosidic extracts enabled us to determine the impact of these precursors on wine's odours (Segurel et al., 2010). The same experimental approach was applied in the context of comparisons by GC-olfactometry (GC-O) to reveal the odour variations between the samples enriched with glycoside precursors.

\section{MATERIALS AND METHODS}

Grenache noir and Syrah wines from vineyards situated in the Southern Cotes du Rhone area, vintage 2001, were selected for this study. Two experimental vineyards were selected, one planted with Grenache noir (GB), and the other with Syrah (SL). Grapes were harvested at technological maturity. For each variety, about $80 \mathrm{~kg}$ of grapes were sampled at random.

The grapes of each experimental vineyard were vinified according to the Inter-Rhone standard winemaking process: grapes were manually harvested, mechanically destemmed and crushed, then put in $1 \mathrm{hL}(100 \mathrm{~L})$ stainless steel tanks. Musts were added with $\mathrm{SO}_{2}$ at $4 \mathrm{~g} / \mathrm{hL}$, and inoculated with $10 \mathrm{~g} / \mathrm{hL}$ of $\mathrm{L} 2056$ commercial yeast strain (Lallemand, France). Fermentation and maceration were carried out during 7 days at $25^{\circ} \mathrm{C}-30^{\circ} \mathrm{C}$. After pressing, malolactic fermentation was performed with addition of Vitilactic bacteria (Martin Vialatte, France). The two wines obtained (Grenache noir GB-01 and Syrah SL-01) were filtered, bottled, and stored at $13^{\circ} \mathrm{C}$ until extraction of their glycosidic precursors. Each glycosidic extract was used as described below.

\section{Synthetic model wines enriched with glycosidic aroma precursors}

a) Synthetic model base wine

To obtain the synthetic model wine, $3.5 \mathrm{~g}$ of tartaric acid were added to $120 \mathrm{~mL}$ of ethanol and $800 \mathrm{~mL}$ of water. The $\mathrm{pH}$ of the mixture was adjusted to 3.5 with 
potassium carbonate and the volume was then adjusted to $1 \mathrm{~L}$ with water.

Two synthetic wines were respectively enriched with pools of glycosidic precursors from wines of Grenache and Syrah, coming from the two experimental plots of Grenache (GB-01) and Syrah (SL-01), in 2001. The preparation of these pools of glycosidic precursors was described in the previous paper (Segurel et al., 2010). They were obtained from $5 \mathrm{~L}$ of wine and the synthetic model wines enriched by a factor 5 with glycosidic extract were analysed by GC-O and Gas Chromatography-Mass Spectrometry (GC-MS). This enrichment permited to increase the detection of the odorants generated from glycosides.

Half of the volume of precursor enriched synthetic wine was added with a commercial enzyme preparation $(50 \mathrm{mg} / \mathrm{L})$ (AR2000, DSM, Delf, Netherlands) containing the following glycosidase activities: $\beta$-D-apiofuranosidase (564.6 nkat/g), $\alpha$-L-rhamnopyranosidase (236.7 nkat/g), $\alpha-\mathrm{L}$-arabinofuranosidase $(13,500 \mathrm{nkat} / \mathrm{g}), \alpha-\mathrm{L}$ arabinopyranosidase (576 nkat/g), and $\beta$-Dglucopyranosidase $(4,380 \mathrm{nkat} / \mathrm{g})$. The samples were closed with screw caps under $\mathrm{CO}_{2}$ atmosphere, homogenized, then stored at room temperature for one week.

These synthetic model wines underwent an accelerated or natural aging, to generate the odorant compounds from these precursors according to the following methods:

Synthetic model wines / Accelerated aging by heating at $45^{\circ} \mathrm{C}$ for three weeks :

- T-Mod: heated synthetic model wine without glycosides addition (control wine),

- G-D-Mod: Enriched with Grenache glycosides / Heated,

- G-DE-Mod: Enriched with Grenache glycosides / Enzyme added/ Heated,

- S-D-Mod: Enriched with Syrah glycosides / Heated,

- S-DE-Mod: Enriched with Syrah glycosides / Enzyme added / Heated.

Synthetic model wines / Natural aging by storage at $13{ }^{\circ} \mathrm{C}$ for eighteen months :

- T-Nat: Synthetic model wine / Natural aging,

- G-D-Nat: Enriched with Grenache glycosides / Natural aging,

- G-DE-Nat: Enriched with Grenache glycosides /Enzyme added / Natural aging,

- S-D-Nat: Enriched with Syrah glycosides / Natural aging,

- S-DE-Nat: Enriched with Syrah glycosides / Enzyme added / Natural aging.

\section{Sensory analysis}

The difference between the synthetic model wines enriched with Grenache noir and Syrah glycosides was determined by carrying out a triangular difference test. Two panels of 17 and 20 judges were respectively used to compare samples submitted to accelerated aging (17 judges) and to natural aging (20 judges). The olfactory assessment of the wines was performed by direct (orthonasal) perception.

\section{GC-MS and GC-O analyses of the volatile compounds}

The volatiles generated by controlled heating with or without enzyme addition were analyzed by GC-O, identified and quantified by GC/MS. At the same time, the synthetic model wines were submitted to natural aging $\left(13{ }^{\circ} \mathrm{C}\right.$ for 18 months) and analysed as above.

\section{a) Extraction}

The volatile compounds were extracted from the samples issued from the two types of aging according to the following method:

$80 \mu \mathrm{g}$ of 3,5-di-tert-butyl-4-hydroxytoluene (BHT), used as internal standard and antioxidant (Escudero and Etiévant, 1999), was added to $125 \mathrm{~mL}$ of a sample. The samples were extracted by $25 \mathrm{~mL}$ of dichloromethane by liquid-liquid extraction, at $4{ }^{\circ} \mathrm{C}$ under nitrogen during $15 \mathrm{~min}$. The emulsion formed was demixed by centrifugation at $4{ }^{\circ} \mathrm{C}(20 \mathrm{~min} ; 8,000 \mathrm{~g})$. The organic phase was separated, then the extraction was repeated one time more. The two organic phases were gathered, dried on anhydrous $\mathrm{Na}_{2} \mathrm{SO}_{4}$ and filtered. The extract was concentrated at $47^{\circ} \mathrm{C}$ in a Vigreux column, then in a Dufton column up to $500 \mu \mathrm{L}$ volume. Extracts were stored under nitrogen at $-80^{\circ} \mathrm{C}$.

\section{b) GC-Olfactometry analyses}

These analyses were performed to focus on the odorants generated from the glycosidic precursors, likely to contribute to the aroma expression of this glycosylated potential, and to the differentiation of both varieties. They were performed in the INRA Laboratory for Aromas in Dijon (UMR Flavic). For each variety, analyses were carried out on extracts from the 5 samples of synthetic model wines submitted to accelerated aging: T-Mod, G-D-Mod, G-DE-Mod, S-D-Mod et S-DE-Mod). The GC-O was carried out using the detection frequency method which consists to register the frequency of perception of an odour by the panelists during the chromatography separation (Van Ruth et al., 1996; Pollien et al., 1997). For each sample, the total duration of analysis was $70 \mathrm{~min}$. To avoid fatigue, each panelist carried out half of the analysis, then the second half was carried 
out by an other panelist. During another session with the same sample injected, the roles were inverted.

Thirteen panelists were selected among 40 candidates to perform the sample analyses. The selection of panelists was carried out using a test of odor recognition (ThomasDanguin et al., 2003), and the training was performed with synthetic solutions containing twenty different odorants. The 13 panelists performed the GC-O analysis of 5 samples. For each sample, the individual olfactograms of each panelist, prompting yes/no responses for an odour (associated to a description of this odour) were juxtaposed, then an aromagram giving the detection frequency, in percentage of subjects having perceived an odour, was obtained by cumulating the individual olfactograms. The description of odours by the panelists was used to facilitate the overlapping of the olfactograms from the different panelists.

For each aging type, natural and accelerated, two analysis on the olfactory difference between Grenache or Syrah synthetic model wines enriched with glycosides were performed, one on enzyme added synthetic model wines (DE), the other on synthetic model wines without enzyme addition (D).

\section{c) Gas chromatography conditions}

A gas chromatograph (Hewlett-Packard 5890 Series II) was fitted with a DB-WAX fused silica capillary column (J\&W SCIENTIFIC; $30 \mathrm{~m}$ x 0.25 mm i.d.; $0.5 \mu \mathrm{m}$ film thickness). Operating conditions were as follows: the injector temperature program was set at $20^{\circ} \mathrm{C}$ to $280^{\circ} \mathrm{C}$ at $180^{\circ} \mathrm{C} \mathrm{min}^{-1}$, then isothermal for $80 \mathrm{~min}$. The oven temperature program was set from $40^{\circ} \mathrm{C}$ to $75^{\circ} \mathrm{C}$ $\left(70^{\circ} \mathrm{C} \mathrm{min}^{-1}\right.$ ) then to $245^{\circ} \mathrm{C}$ at $3^{\circ} \mathrm{C} \mathrm{min}^{-1}$, then isothermal for $20 \mathrm{~min}$. Hydrogen carrier gas flow-rate was $1.5 \mathrm{~mL}$ $\mathrm{min}^{-1}$. The column outlet was fitted with a fixed divider to an olfactometric detector ( $2 / 3$ of the flow) and to a flame ion detector ( $1 / 3$ of the flow). The injector and the detector were kept at $280^{\circ} \mathrm{C}$. The injected volume was $1.5 \mu \mathrm{L}$.

\section{d) Detection by GC-O}

The transfer column carrying the chromatographic effluent was kept at $280^{\circ} \mathrm{C}$, connected to a glass sniffing port adjusted to the human nose. The effluent reaching the sniffing port was carried by a humidified air make up $\left(100 \mathrm{~mL} \mathrm{~min}^{-1}\right)$. Each panellist indicated each odour he perceived by a click of the computer's mouse. Simultaneously, the recording of every perceived odour was made on a tape recorder. The yes/no response to an odour expressed by the click of the mouse according to elution time was obtained by Fingerclick, a specifically designed software (INRA-UMR Flavic, Dijon, France).

\section{e) Treatment of olfactometric data}

The Fingerclick software was used to perform the following successive operations for each extract : the 13 individual olfactograms were cumulated to establish the aromagram giving the detection frequencies in percentage, (number of citations of a detected odour at the same linear retention time/number of panellists x 100).

\section{f) Gas chromatography / Mass Spectrometry}

The gas chromatography separation was carried out as previously described. For the mass spectrometry, a Hewlett-Packard 5889 A mass spectrometer equipped with a quadrupole detector was used for electron impact (EI) mode spectra. The transfer line from GC to MS was heated to $250{ }^{\circ} \mathrm{C}$. The source temperature was kept at $250{ }^{\circ} \mathrm{C}$. EI was recorded at $70 \mathrm{eV}$ in the mass range of m/e 29-350 at 1 s intervals (fullscan mode). Identifications were carried out by comparing the linear retention index, EI mass spectra, and the odour descriptors of the compounds eluted, with published data or with data from authentic compounds; $1 \mu \mathrm{L}$ was injected. The compounds were quantified by correlating the peak areas to 4-nonanol used as internal standard ( $16.3 \mu \mathrm{L} / 100 \mathrm{~mL}$ of sample). Results (means of four replications) were expressed as 4-nonanol equivalent.

\section{RESULTS AND DISCUSSION}

The sensory analyses of wines enriched with glycosides, described in the previous paper (Ségurel et al., 2009), have demonstrated the implication of the grape glycosidic potential in the aroma of Grenache noir and Syrah wines, particularly in their aroma differentiation. In this paper, synthetic model wines enriched with Grenache or Syrah glycosides extracts, with or without enzyme addition, were submitted to aging treatments similar to those used in the sensory analyses (Ségurel $e t$ al., 2009). However, in this case, the glycoside extracts were not added to wine but to synthetic model wines in order to make easier the GC-O and GC-MS analysis of the volatiles arising from glycoside, the only source of volatiles in such samples.

\section{Preliminary difference test}

Before performing such extensive analysis, the intervarietal difference of the aromas generated from the different preparations was checked by comparative sensory analysis using the triangular test as previously described (Ségurel et al., 2009). For each aging type, natural and accelerated, the olfactory difference between Grenache or Syrah synthetic model wines enriched with glycosides was significant in each case: $(p=0.01)$ for the D solutions (without enzyme addition) and for the DE solutions (with enzyme addition) $(p=0.001)$, indicating that the aromatic 
expression of glycosidic precursors in the model solution differentiated significantly the two varieties for the two aging modes. However, the difference seemed to be more difficult to perceive in the case of natural aging without enzyme addition. This could be explained by the relatively short time of natural aging $\left(18\right.$ months at $\left.13^{\circ} \mathrm{C}\right)$, whereas model aging and enzyme addition increased the differences between aromas of Grenache and Syrah synthetic wines.

\section{GC-O analyses}

a) Odorant compounds profiles generated by accelerated aging of the model solutions

Four areas, perceived in the T-Mod sample of the non enriched heated synthetic model wines, were eliminated from the other aromagrams as they were generated from the matrix and not from glycosides. Among the 4 aromagrams, corresponding to the G-D-Mod, S-D-Mod, G-DE-Mod et S-DE-Mod samples, 186 odorant areas were perceived at least by one judge, giving evidence of the aroma complexity of the extracts, but 86 odours were perceived by only one panelist. Only 70 odours, perceived by at least $30 \%$ of the panel (4 panelists out of 13), were retained as significant as previously reported, regardless of the size of the jury (Pollien et al., 1997, Aubry, 1999, Bernet, 2000). These odorous areas were often perceived in the 4 samples with different detection frequencies (figures 1 and 2).

The total average of the detection frequencies of all the odours perceived for each aromagram did not differ more than $5 \%$ between the varieties, for the same preparations (with or without enzyme addition): $47 \%$ for G-D-Mod against $50 \%$ for S-D-Mod (figure 1), and 63\% for G-DE-Mod against $57 \%$ for S-DE-Mod (figure 2). However, the enzyme addition increased this average intensity from $50 \%$ to $57 \%$ for Syrah and from $47 \%$ to $63 \%$ for Grenache. Thus, enzyming enhanced the aromatic intensity more significantly for Grenache synthetic model wines.

Similarities and differences appeared between the varieties concerning the detection frequencies of different odorous areas. To compare these detection frequencies, the least significant difference (LSD) of $30 \%$, reported in the literature, was generally admitted. However, as this threshold is liable to variations depending of the odor, we decided to choose a less restrictive LSD of 3 panelists, corresponding to a frequency of $23 \%$ ( 3 panelists out of 13 ), to prevent removing any potentially discriminating areas.

\section{b) Odorous areas common to the both varieties}

The odour areas with detection frequency difference between varieties less than $23 \%$ are shown in table 1 .

Some of the compounds identified in these odours had already been identified as aglycones in the bound fraction of the aroma of Grenache and Syrah berries (Ségurel, 2005). Among them were non terpenic alcohols (butan-1-ol, 2- and 3-methyl butanols, heptan-2-ol, 1-octen-3-ol, 2-phenylethanol), $\mathrm{C}_{6}$-compounds (hexan1-ol, (Z)-hexen-3-ol), volatile phenols (methyl salicylate,

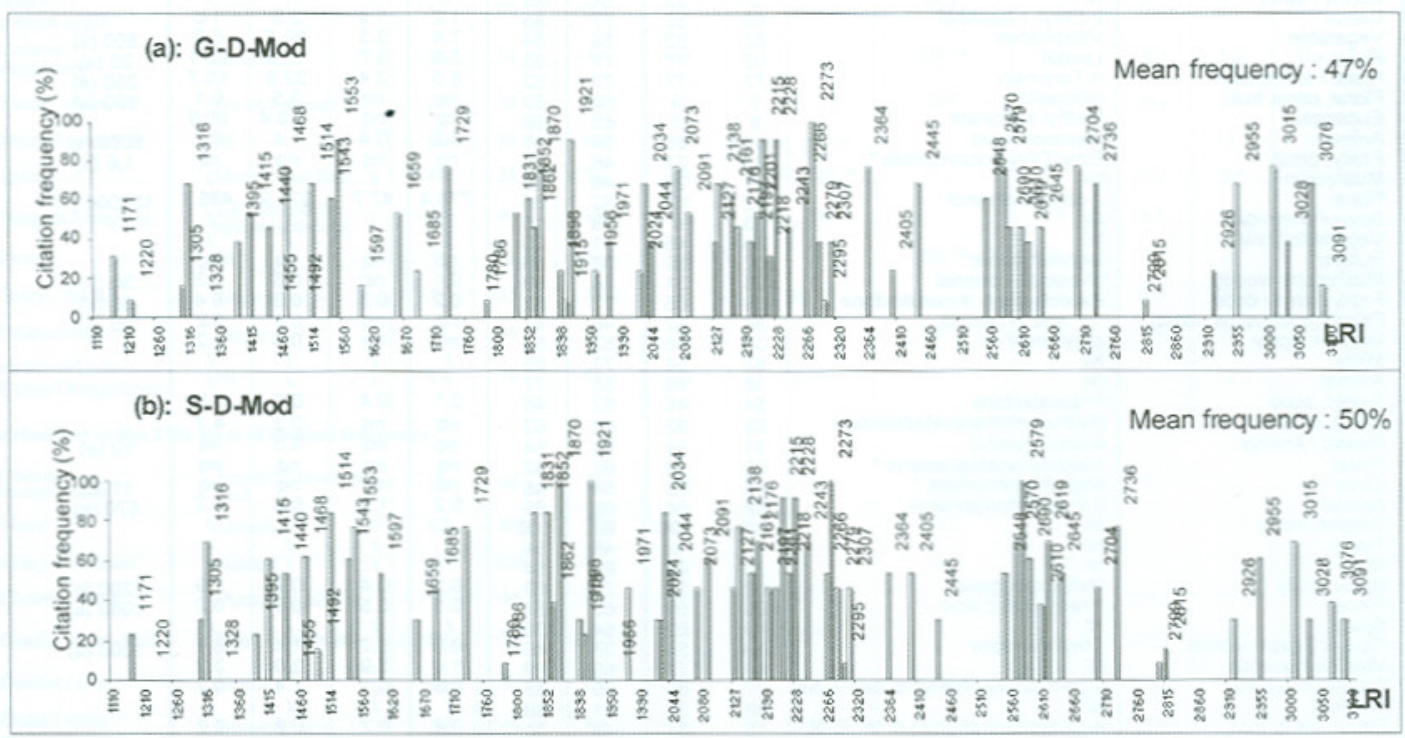

Figure 1 - Aromagrams of two volatile extracts, from model wine solutions added with glycoconjugates

of (a): Grenache noir wine (G-D-Mod sample), (b): Syrah wine (S-D-Mod sample) and submitted to model aging (controlled heating, $45^{\circ} \mathrm{C}$ for three weeks). 

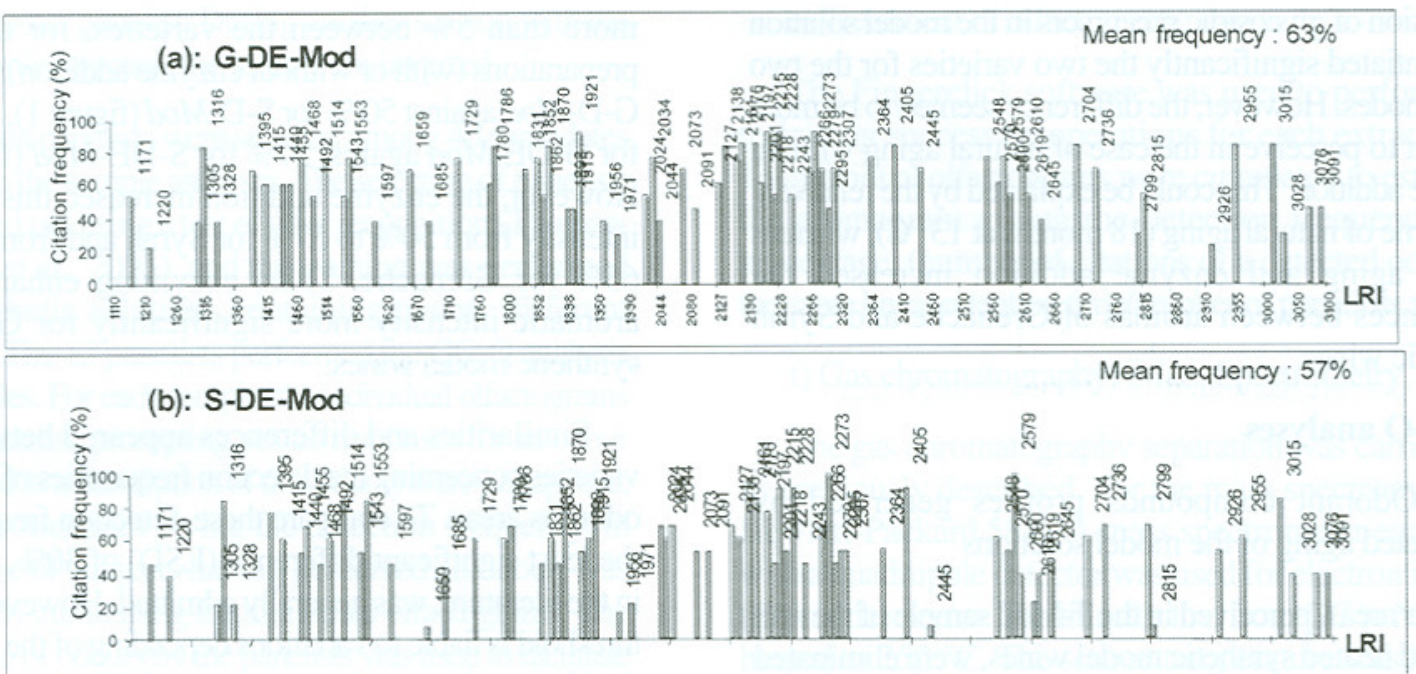

Figure 2 - Aromagrams of two volatile extracts, from model wine solutions added with glycoconjugates of (a): Grenache noir wine (G-DE-Mod sample), (b): Syrah wine (S-DE-Mod sample),

enzymed with glycosidasic preparation, and submitted to model aging (controlled heating, $45^{\circ} \mathrm{C}$ for 3 weeks). Citation frequency (\% of panelists perceiving an odor) as a function of LRI: Linear Retention Index during the GC analysis performed on polar type column (DBWAX)

Table 1 - Odorant compounds generated by glycoconjugates after model aging: qualitative and quantitative analysis by GC-Olfactometry. Odors common to Grenache and Syrah, i.e. for which citation frequency in Grenache and Syrah samples do not differ more than $23 \%$ among one modality (enzymed or not).

\begin{tabular}{|c|c|c|c|c|c|c|c|c|c|c|c|}
\hline $\mathrm{RI}^{\mathrm{a}}$ & Odor description $^{b}$ & Identification $^{c}$ & \multicolumn{4}{|c|}{$\begin{array}{l}\text { Odor citation } \\
\text { frequency }(\%)^{d}\end{array}$} & \multicolumn{4}{|c|}{ Concentration $(\mu \mathrm{g} / \mathrm{L})^{\mathrm{c}}$} & $\begin{array}{l}\text { Olfactive } \\
\text { perception } \\
\text { threshold }^{f}\end{array}$ \\
\hline $\begin{array}{l}1171 \\
1220 \\
1305 \\
1316 \\
1328 \\
1395 \\
1415 \\
1440 \\
1455 \\
1492 \\
1514 \\
1543 \\
1553 \\
1729 \\
1780 \\
1786 \\
1862 \\
1898 \\
1915 \\
1921 \\
1956 \\
1971 \\
1987 \\
2024 \\
2034 \\
2091 \\
2127 \\
2161 \\
2197 \\
2201 \\
2215 \\
2218 \\
2228 \\
2243 \\
2266 \\
2273 \\
2295 \\
2307 \\
2548 \\
2570 \\
2590 \\
2645 \\
2736 \\
3015 \\
3028 \\
3091\end{array}$ & $\begin{array}{l}\text { Herbaceous } \\
\text { Gas, Alcohol } \\
\text { Lemon } \\
\text { Mushroom } \\
\text { Cooking } \\
\text { Fruity / herbaceous } \\
\text { Mushroom } \\
\text { Fruity } \\
\text { Mushroom } \\
\text { Earthy / spicy } \\
\text { Carrot } \\
\text { Vegetable } \\
\text { Floral } \\
\text { Floral / toothpaste } \\
\text { Floral, citrus fruit } \\
\text { Eucalyptus } \\
\text { Animal } \\
\text { Fruity, citrus } \\
\text { Mushroom } \\
\text { Floral } \\
\text { Spicy / chemical } \\
\text { Vegetable/floral } \\
\text { Rubber } \\
\text { Mushroom, woody } \\
\text { Fruity / anis / coco } \\
\text { Floral / eucalyptus / coco } \\
\text { Leather, spicy } \\
\text { Minty } \\
\text { Animal } \\
\text { Sweet, coco } \\
\text { Spicy, coffee } \\
\text { Plastic / Animal } \\
\text { Floral } \\
\text { Coco } \\
\text { Animal } \\
\text { Dentist, minty } \\
\text { Floral } \\
\text { Minty } \\
\text { Spicy, fruity } \\
\text { Floral } \\
\text { Spicy } \\
\text { Spicy / Floral / vanilla } \\
\text { Wax/herbaceous } \\
\text { Candy, berry fruit } \\
\text { Medical } \\
\text { Floral, berry fruit } \\
\end{array}$ & 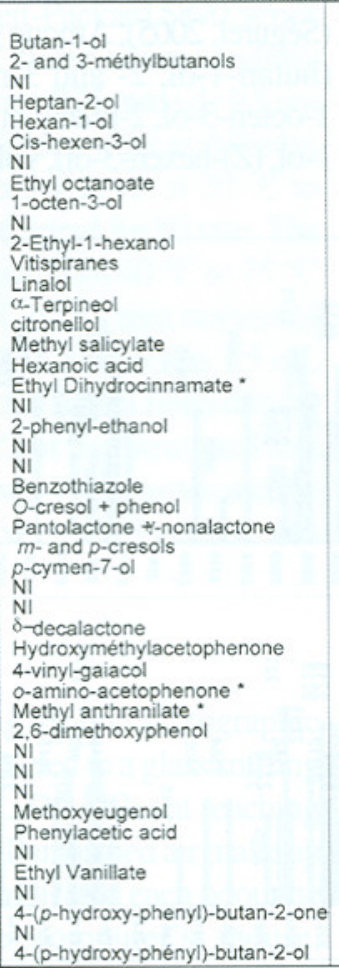 & 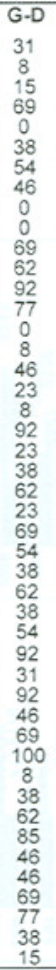 & $\begin{array}{c}S-D \\
23 \\
0 \\
31 \\
69 \\
0 \\
23 \\
62 \\
54 \\
0 \\
15 \\
85 \\
62 \\
77 \\
77 \\
0 \\
8 \\
38 \\
31 \\
23 \\
100 \\
0 \\
46 \\
62 \\
31 \\
85 \\
62 \\
46 \\
54 \\
46 \\
46 \\
92 \\
54 \\
92 \\
62 \\
54 \\
100 \\
8 \\
46 \\
54 \\
69 \\
62 \\
62 \\
54 \\
77 \\
69 \\
31 \\
31\end{array}$ & $\begin{array}{c}\mid \text { G-DE } \\
54 \\
23 \\
38 \\
85 \\
38 \\
69 \\
62 \\
62 \\
62 \\
54 \\
77 \\
54 \\
77 \\
77 \\
62 \\
85 \\
54 \\
46 \\
46 \\
92 \\
38 \\
31 \\
92 \\
54 \\
77 \\
46 \\
62 \\
77 \\
85 \\
62 \\
92 \\
54 \\
92 \\
94 \\
69 \\
9 \\
92 \\
46 \\
69 \\
77 \\
62 \\
54 \\
38 \\
69 \\
85 \\
31 \\
46\end{array}$ & $\begin{array}{l}\text { S-DE } \\
46 \\
38 \\
23 \\
85 \\
23 \\
77 \\
62 \\
54 \\
69 \\
62 \\
85 \\
54 \\
85 \\
62 \\
62 \\
69 \\
46 \\
54 \\
62 \\
85 \\
15 \\
23 \\
69 \\
69 \\
62 \\
54 \\
69 \\
85 \\
77 \\
46 \\
92 \\
54 \\
92 \\
46 \\
69 \\
100 \\
54 \\
54 \\
62 \\
54 \\
38 \\
46 \\
69 \\
85 \\
38 \\
38\end{array}$ & $\begin{array}{c}\text { G-D } \\
\text { nq } \\
10.0 \\
\text { nq } \\
\text { nq } \\
\text { nq } \\
1 \\
23.7 \\
\text { nq } \\
1 \\
1.2 \\
7.6 \\
2.5 \\
5.5 \\
\text { nq } \\
\text { nq } \\
0.2 \\
\text { nq } \\
7 \\
778.4 \\
1 \\
1 \\
\text { nq } \\
0.1 \\
0.2 \\
\text { nq } \\
\text { nq } \\
1 \\
\end{array}$ & $\begin{array}{c}\text { S-D } \\
\text { nq } \\
11.4 \\
I \\
\text { nq } \\
\text { nq } \\
\text { nq } \\
1 \\
16.2 \\
\text { nq } \\
1 \\
1.4 \\
3.3 \\
3.7 \\
3.4 \\
\text { nq } \\
\text { nq } \\
0.4 \\
\text { nq } \\
\\
47.7 \\
\end{array}$ & $\begin{array}{c}\text { G-DE } \\
2.7 \\
50.1 \\
I \\
3.2 \\
289.4 \\
26.2 \\
1 \\
69.1 \\
8.0 \\
1 \\
2.8 \\
20.7 \\
12.9 \\
32.9 \\
0.5 \\
118.4 \\
1.4 \\
\text { nq } \\
1 \\
978.9 \\
1 \\
1 \\
\text { nq } \\
0.5 \\
0.3 \\
0.4 \\
0.3 \\
j \\
1 \\
0.6 \\
0.3 \\
0.5 \\
\text { nq } \\
\text { nq } \\
0.6 \\
1 \\
1 \\
1 \\
0.7 \\
0.6 \\
1.4 \\
3.0 \\
1.4 \\
0.8 \\
0.8\end{array}$ & $\begin{array}{c}\text { S-DE } \\
2.5 \\
66.0 \\
j \\
4.1 \\
153.7 \\
12.9 \\
1 \\
45.9 \\
3.2 \\
1 \\
1.6 \\
5.5 \\
22.1 \\
16.7 \\
0.1 \\
90.9 \\
0.2 \\
\text { nq } \\
1 \\
486.7 \\
1 \\
1 \\
\text { nq } \\
0.3 \\
0.4 \\
0.2 \\
1.2 \\
1 \\
1 \\
0.8 \\
4.7 \\
\text { nq } \\
\text { nq } \\
\text { nq } \\
0.7 \\
1 \\
1 \\
1 \\
2.9 \\
0.2 \\
1 \\
6.7 \\
3.2 \\
0.2 \\
1 \\
0.2 \\
\end{array}$ & $\begin{array}{c}150000(\mathrm{v}) \\
180000(\mathrm{v}) \\
2500(\mathrm{v}) \\
5000(\mathrm{v}) \\
400(\mathrm{~s}) \\
580(\mathrm{v}) \\
200(\mathrm{~b}) \\
\\
800(\mathrm{v}) \\
25(\mathrm{~s}) \\
250(\mathrm{~s}) \\
100(\mathrm{~s}) \\
8000(\mathrm{v}) \\
1,6(\mathrm{~s}) \\
100000(\mathrm{v})\end{array}$ \\
\hline
\end{tabular}

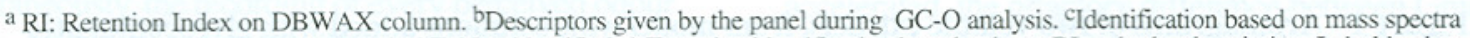
and analysis of reference compounds; NI: Non identified; * Tentative identification based only on RI and odor description. In boldscript: compounds previously identified in the glycosylated fraction of the corresponding grapes. ${ }^{\mathrm{d}}$ The four samples correspond to extracts of model wines added with glycoconjugates extracted from Grenache noir $(G)$ or Syrah (S), enzymed with glycosidasic preparation or not (DE or $\mathrm{D})$, and submitted to model aging treatment (controlled heating at $45^{\circ} \mathrm{C}$ for 3 weeks. 'Estimated concentration, in equivalents of BHT,

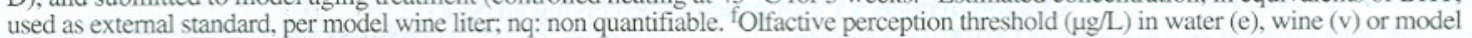
wine (s), according to literature (Simpson, 1978; Etiévant, 1991; Culléré et al., 2004). 
methoxyeugenol, acetovanillone), and monoterpenols (linalol, $\alpha$-terpineol, citronellol). The vitispiranes, identified at the index retention $I R=1543$, were generated from a glycosylated norisoprenoidic triol $(3,6,9$ trihydroxy-7,8-dihydro- $\beta$-ionol) occurring in grape berry (Winterhalter, 1991; 1992).

GC/MS of the areas around the retention index 2210 revealed numerous compounds, including an isomer of the methyl-hydroxy-acetophenone, already identified in the glycosidic fraction of berries (Ségurel, 2005). This compound had only been quantified in the samples with enzyme addition (table 1). As in the bound fraction of the berries, it seemed to be more abundant in the Syrah than in the Grenache samples (Ségurel, 2005), but the observed $\mathrm{GC}-\mathrm{O}$ frequencies did not confirm this difference.

Other compounds had not been identified in the glycosylated fraction of the berries. However, several phenolic compounds were previously found in the bound fraction of the aroma of Syrah berries or leaves, particularly phenol, cresols, 2,6-dimethoxyphenol, 4-(4-hydroxyphenyl)-butan-2-one (frambinone) and its corresponding alcohol 4-(4-hydroxyphenyl)-butan-2-ol (Wirth et al., 2001).

It was interesting to note the presence of lactones (pantolactone, $\gamma$-nonalactone, $\delta$-decalactone). Some lactones have been also previously found in acid hydrolysates of precursors extracts from Grenache noir grapes (Lopez et al., 2004). However, such lactones, specially $\delta$-decalactone, have been already found in the hydrolysates enzymatically obtained from glycoconjugates of several fruits like raspberry, pineapple and several varieties of peaches and nectarines (Pabst et al., 1991, Wu et al., 1991; Aubert et al., 2003). They could arise from glycosides of their open form (5-hydroxydecanoic acid in the case of $\delta$-decalactone), by hydrolysis followed by cyclization; this mechanism has already been demonstrated for whisky-lactone (Masson et al., 2000) and marmelolactone (Winterhalter et al., 1991).

Finally, ethyl octanoate and ethyl dihydrocinnamate could be generated by the glycoside hydrolysis of the corresponding acids, followed by the esterification of

Table 2 - Odorant compounds generated by glycoconjugates. Odors discriminating Grenache and Syrah samples.

\begin{tabular}{|c|c|c|c|c|c|c|c|c|c|c|c|c|c|}
\hline \multirow{2}{*}{$\mathrm{RI}^{\mathrm{a}}$} & \multirow{2}{*}{$\begin{array}{c}\text { Odor } \\
\text { description }^{b}\end{array}$} & \multirow{2}{*}{ Identification $^{\mathrm{e}}$} & \multicolumn{4}{|c|}{ Odor Citation frequency $(\%)^{4}$} & \multirow{2}{*}{$\begin{array}{l}\text { Odors } \\
\text { predominant } \\
\text { in Grenache* }\end{array}$} & \multirow{2}{*}{$\begin{array}{c}\text { Odors } \\
\text { predominant } \\
\text { in Syrah * }\end{array}$} & \multicolumn{4}{|c|}{ Concentration $(\mu \mathrm{g} / \mathrm{L})^{e}$} & \multirow{2}{*}{$\begin{array}{l}\text { Olfactive } \\
\text { perception } \\
\text { threshold }\end{array}$} \\
\hline & & & $G-D$ & S-D & G-DE & S-DE & & & G-D & S-D & G-DE & S-DE & \\
\hline \multicolumn{14}{|c|}{ Odors discriminant at the $30 \%$ level of citation frequency } \\
\hline 1468 & Cooking / potatoe & $\begin{array}{l}\text { 3-methyl-thio } \\
\text {-propanal }\end{array}$ & 77 & 62 & 77 & 46 & $\mathrm{DE}^{30}$ & & $\mathrm{Nq}$ & $\mathrm{Nq}$ & $\mathrm{Nq}$ & $\mathrm{Nq}$ & $0.15(\mathrm{~s})$ \\
\hline 1597 & $\begin{array}{l}\text { Vegetable/ } \\
\text { cucumber }\end{array}$ & $\begin{array}{l}(E, Z)-N o n a-2,6- \\
\text { dienal }\end{array}$ & 15 & 54 & 38 & 46 & & $D^{*}$ & $\mathrm{Nq}$ & $\mathrm{Nq}$ & $\mathrm{Nq}$ & $\mathrm{Nq}$ & $0.02(s)$ \\
\hline 1659 & Floral & Riesling acetal & 54 & 31 & 69 & 8 & $\mathrm{D}^{23}, \mathrm{DE}^{30}$ & & 1.1 & 0.5 & 2.7 & 0.5 & \\
\hline 1831 & $\begin{array}{l}\text { Fruity ' } \\
\text { cooked apple }\end{array}$ & $\beta$-damascenone & 54 & 85 & 69 & 46 & DE23 & $D^{3}$ & 0.2 & 0.4 & 0.3 & 0.3 & $0.05(\mathrm{~s})$ \\
\hline 2044 & $\begin{array}{l}\text { Caramel/ } \\
\text { strawberry }\end{array}$ & Furaneol & 38 & 54 & 38 & 69 & & $\mathrm{DE}^{30}$ & $\mathrm{Nq}$ & $\mathrm{Nq}$ & $\mathrm{Nq}$ & $\mathrm{Nq}$ & $5(s)$ \\
\hline 2405 & Floral / chemical & 4-vinyl-phenol & 23 & 54 & 85 & 92 & & $D^{\infty}$ & $\mathrm{Nq}$ & $\mathrm{Nq}$ & 4.3 & 2.1 & $180(s)$ \\
\hline 2445 & Minty / spiced & NI & 69 & 31 & 69 & 8 & $D^{30}, D^{30}$ & & l & 1 & , & 1 & \\
\hline 2610 & Spiced & Methyl vanillate & 46 & 38 & 77 & 23 & $\mathrm{D}^{23}, \mathrm{DE}^{30}$ & & 0.1 & 0.1 & 0.6 & 0.3 & $3000(s)$ \\
\hline 2704 & Pungent / hospital & $\begin{array}{l}\text { 3,4-dihydro-3- } \\
\text { hydoxyactinidol }\end{array}$ & 77 & 46 & 85 & 62 & $\mathrm{D}^{30}, \mathrm{DE}^{23}$ & & 4.9 & 0.8 & 5.8 & 0.9 & \\
\hline 2799 & Floral & $\mathrm{NI}$ & 0 & 8 & 31 & 69 & & $\mathrm{DE}^{30}$ & $\gamma$ & l & f & I & \\
\hline 2815 & Spicy / fresh & Zingerone & 8 & 15 & 54 & 8 & $\mathrm{DE}^{30}$ & & 0.5 & 0.3 & 15.7 & 5.1 & \\
\hline 2926 & Undescribed & Zingerol & 23 & 31 & 23 & 54 & & $\mathrm{DE}^{30}$ & 1.4 & 0.9 & 3.8 & 1.4 & \\
\hline 3076 & $\begin{array}{l}\text { charcoslEuca- } \\
\text { lyptus/Orange/coco }\end{array}$ & $\mathrm{Nl}$ & 69 & 38 & 46 & 38 & $\mathrm{D}^{30}$ & & 1 & 1 & I & t & \\
\hline \multicolumn{14}{|c|}{ Odors diseriminant at the $23 \%$ level of citation frequency } \\
\hline 1685 & $\begin{array}{l}\text { Cheese' } \\
\text { transpiration }\end{array}$ & $\begin{array}{l}\text { 3-methyl-butanoic } \\
\text { acid }\end{array}$ & 23 & 46 & 38 & 38 & & $D^{23}$ & 0.1 & 0.2 & 0.1 & 0.2 & $8(s)$ \\
\hline 1852 & Floral & Geraniol & 62 & 85 & 77 & 62 & & $D^{23}$ & 0.1 & 0.2 & 1.4 & 2.9 & \\
\hline 1870 & Minty / medical & Gaiacol & 77 & 100 & 85 & 92 & & $D^{23}$ & $\mathrm{Nq}$ & 0.2 & 0.2 & 1.2 & $9.5(\mathrm{~s})$ \\
\hline 2073 & Cheese / dusty & Octanoic acid & 77 & 46 & 69 & 54 & $D^{23}$ & & 128.9 & 96.9 & 141.1 & 76.9 & $500(\mathrm{~s})$ \\
\hline 2138 & Candy / berry fruit & Ethyl cinnamate & 69 & 77 & 85 & 62 & $\mathrm{DE}^{23}$ & & 0.1 & $\mathrm{Nq}$ & 0.7 & 0.4 & $1.1(\mathrm{~s})$ \\
\hline 2176 & Dentist / clove & Eugenol & 46 & 69 & 85 & 85 & & $D^{23}$ & $\mathrm{Nq}$ & $\mathrm{Nq}$ & 0.2 & 0.9 & $6(s)$ \\
\hline 2279 & $\begin{array}{l}\text { Burnt / spicy / } \\
\text { rubber }\end{array}$ & Decanoic acid & 38 & 46 & 69 & 46 & $\mathrm{DE}^{23}$ & & 30.5 & 23.3 & 32.7 & 16.2 & $1000(\mathrm{~s})$ \\
\hline 2364 & Spicy / floral & NI & 77 & 54 & 77 & 54 & $\mathrm{D}^{23}, \mathrm{DE}^{23}$ & & 0.1 & 0.1 & 0.1 & 0.2 & $6(\mathrm{~s})$ \\
\hline 2579 & Vanilla & Vanilline & 100 & 100 & 92 & 100 & & $\mathrm{D}^{23}, \mathrm{DE}^{23}$ & 1.6 & 2.5 & 4.1 & 2.5 & $60(\mathrm{~s})$ \\
\hline 2955 & Sweet / chocolate & Syringaldéhyde & 69 & 62 & 85 & 62 & $\mathrm{DE}^{23}$ & & 1.3 & 2.8 & 3.2 & 2.6 & $50000(\mathrm{e})$ \\
\hline
\end{tabular}

a, b, c, d, e, f see table 1. * Odors for which there is a difference in citation frequency between Grenache and Syrah of $23 \%$ or $30 \%$ at least, while comparing among non enzymed modalities (D) or enzymed (DE). 
these acids, under the conditions of the accelerated model aging.

c) Odorant areas potentially differentiating the two varieties

We could distinguish 23 odour areas which differentiate the two varieties with a detection frequency difference higher than 23\% (table 2): 13 odour areas predominated in the Grenache samples and 11 predominated in the Syrah. Differences of detection frequency between the enzyme added samples (G-DEMod vs S-DE-Mod) was above $50 \%$ for 4 odours characterizing Grenache, whereas it reached exactly $30 \%$ for all the areas characterizing Syrah. That demonstrated the more important effect of enzyme addition on the Grenache variety, in accordance with the sensory analyses of wines enriched with glycosides (Ségurel et al., 2009).

The analysis by GC-MS allowed the identification of 20 possible compounds for these odours, however 4 areas were unknown (table 2).

Among the compounds differentiating both varieties, three $\mathrm{C} 13$-norisoprenoids were identified: Riesling acetal $(\mathrm{RI}=1659$ ), contributing to the typicity of old Riesling wines (Strauss et al., 1987; Winterhalter et al., 1990); $\beta$-damascenone $(R I=1831)$ a powerful odorant in wines (Ferreira et al., 2002; Lopez et al., 2004); and 3,4-dihydro3 -hydroxyactinidol $(\mathrm{RI}=2704)$. These three compounds were generated from glycosylated precursors occurring in grape berry as reported previously (Strauss et al., 1987; Winterhalter et al., 1990; 1991). Riesling acetal and 3-hydroxy-3,4-dihydroactinidol odours were more intense in Grenache samples with or without enzyme treatment. $\beta$-damascenone predominated in Syrah sample without enzyme addition (S-D), but its odour was more intense in enzyme added Grenache sample (G-DE). That could be explained by the different reactivities of its precursors, free aglycones or glycosides (Winterhalter and Skouroumounis, 1997).

Nine volatile phenols differentiated both varieties: Methyl vanillate, zingerone, zingerol and 4-vinyl-phenol displayed the most significant differences in olfactory intensities (threshold $\geq 30 \%$ ), the first two odorants characterizing Grenache, and the latter ones Syrah. That was consistent with the higher levels in zingerone and zingerol aglycones in the glycosidic fraction from the Grenache berries, but the other phenolic aglycones did not show significant differences in the berries of both varieties (Ségurel, 2005). With a lower detection frequency difference $(\geq 23 \%)$, gaiacol, eugenol and vanillin could contribute to the aromatic typicity of Syrah wines. The odour area perceived at the retention index IR $=2044$, more intense in the Syrah samples, was attributed to furaneol, based on its odour descriptors of caramel/strawberry jam only as it could not be detected using GC-MS. This compound was also found in the GC$\mathrm{O}$ analysis of several old red wines (Kotseridis and Baumes, 2000, Aznar et al., 2001; Cullere et al., 2004). The furaneol contents in these samples, and in the corresponding glycosidic extracts, were probably underestimated due to the high polarity of the glucosides, making them difficult to extract from juices or wines (Kotseridis, 1999). Moreover, this compound could act in synergy with other keto-enols odorants such as homofuraneol and sotolon (Ferreira et al., 2002).

Lastly, ethyl cinnamate, 3-methyl-butanoic acid, nona2,6-dienal and 3-methylthiopropanal (methional) were detected in the samples of both varieties. The two aldehydes were only identified using their retention index and their characteristic odour descriptor (respectively cucumber and boiled potato). They were frequently reported in GC-O studies due to their formation in oxidized wines and their very low perception thresholds (Escudero et al., 2000).

d) Odorant compound profiles generated by natural aging of model solutions of wines enriched with glycosides

The previously identified aroma compounds were quantified in the natural aged samples (table 3). Several compounds could not be quantified in the two samples without enzyme treatment (G-D-Nat et S-D-Nat), many more than in the corresponding accelerated model aging (G-D-Mod et S-D-Mod) (tables 1 and 2). Thus, the natural aging conditions used 18 months of storage at $13{ }^{\circ} \mathrm{C}$ was less efficient in generating odorants from glycosides than model aging conditions, which was consistent with the sensory analysis of wines enriched with glycosides (Ségurel et al., 2009).

A principal component analysis (PCA) was carried out on the detection frequencies of the odorants identified by $\mathrm{GC} / \mathrm{O}$, in the 8 samples of both varieties submitted to model and natural aging, but odorants differentiating both varieties only were used (figure 3 ). In the PCA first plane, most variables were located in the Eastern part of the correlation circle, thus characterized by the abundance of compounds. The samples were separated according to the variety and the enzyme treatment, whereas the two aging modes Mod and Nat were grouped, which validated the thermal aging as a good model for natural aging. The first axis ( $49.7 \%$ of variability) separated the samples without enzyme addition in the Western zone, from the enzyme added samples, in the Eastern zone. The second axis (30.3\% of variability) separated the Grenache from the Syrah samples. Both varieties were clearly separated when enzyme added samples were considered. Similarly, enzyme treatment differentiated more easily the Grenache than the Syrah samples, as already observed in the sensory analysis (Ségurel et al., 2009) and the model aged samples. 
Table 3 - Amounts of odorant compounds in model wines added with glycoconjugates extracted from Grenache noir (G) or Syrah (S), and submitted to natural aging (storage at $13{ }^{\circ} \mathrm{C}$ for 18 months).

\begin{tabular}{|c|c|c|c|c|c|}
\hline \multirow[t]{2}{*}{$\mathbf{R I}^{\mathbf{a}}$} & \multirow[t]{2}{*}{ Odorant compound ${ }^{a}$} & \multicolumn{4}{|c|}{ Concentration $(\mu \mathrm{g} / \mathrm{L})^{\mathrm{b}}$} \\
\hline & & G-DE-Nat & S-DE-Nat & G-D-Nat & S-D-Nat \\
\hline \multicolumn{6}{|c|}{ Compounds attributed to odors discriminant at the $30 \%$ level of citation frequency in GC-O } \\
\hline 1468 & 3-methyl-thio-propanal & $\mathrm{Nd}$ & Nd & $\mathrm{Nd}$ & $\mathrm{Nd}$ \\
\hline 1597 & $(E, Z)$-Nona-2,6-dienal & $\mathrm{Nd}$ & $\mathrm{Nd}$ & $\mathrm{Nd}$ & $\mathrm{Nd}$ \\
\hline 1659 & Riesling acetal & 0.20 & 0.01 & 0.40 & 0.07 \\
\hline 1831 & $\beta$-damascenone & 0.05 & 0.05 & 0.05 & 0.08 \\
\hline 2044 & Furaneol & $\mathrm{Nd}$ & $\mathrm{Nd}$ & $\mathrm{Nd}$ & $\mathrm{Nd}$ \\
\hline 2405 & 4-vinyl-phenol & Nd & $\mathrm{Nd}$ & 2.09 & 2.05 \\
\hline 2610 & Methyl Vanillate & 1.53 & 4.82 & 4.55 & 6.72 \\
\hline 2704 & 3,4-dihydro-3-hydroxyactinidol & Nd & Nd & $\mathrm{Nd}$ & Nd \\
\hline 2704 & 3 -[(2-hydroxyethyl)-thio]-hexan-1-ol & 4.07 & 0.59 & 0.5 & $\mathrm{Nd}$ \\
\hline 2815 & Zingerone & 0.41 & $\mathrm{Nd}$ & 8.06 & 3.74 \\
\hline 2926 & Zingerol & 1.25 & 0.49 & 2.01 & 1.13 \\
\hline \multicolumn{6}{|c|}{ Compounds attributed to odors discriminant at the $23 \%$ level of citation frequency in GC-O } \\
\hline 1685 & 3-methyl-butanoic acid & $\mathrm{Nd}$ & 0.02 & 1.43 & 0.14 \\
\hline 1852 & Geraniol & $\mathrm{Nd}$ & $\mathrm{Nd}$ & 1.60 & 4.35 \\
\hline 1870 & Gaiacol & $\mathrm{Nd}$ & $\mathrm{Nd}$ & 0.07 & 1.12 \\
\hline 2073 & Octanoic acid & 84.07 & 44.9 & 69.75 & 38.83 \\
\hline 2138 & Ethyl cinnamate & 0.22 & $\mathrm{Nd}$ & 0.24 & 0.31 \\
\hline 2176 & Eugenol & $\mathrm{Nd}$ & $\mathrm{Nd}$ & 0.11 & 0.85 \\
\hline 2279 & Decanoic acid & 17.20 & 10.67 & 9.26 & 6.24 \\
\hline 2579 & Vanillin & 0.87 & 0.87 & 1.27 & 1.46 \\
\hline 2955 & Syringaldehyde & 0.82 & 0.73 & 0.98 & 0.94 \\
\hline \multicolumn{6}{|c|}{ Compounds attributed to odor common to Grenache and Syrah } \\
\hline $\begin{array}{l}1171 \\
1220\end{array}$ & Butan-1-ol & $\begin{array}{l}\text { Nd } \\
4.15\end{array}$ & $\begin{array}{l}\text { Nd } \\
4.50\end{array}$ & $\begin{array}{c}1.28 \\
21.97\end{array}$ & $\begin{array}{c}1.77 \\
30.23\end{array}$ \\
\hline $\begin{array}{l}1220 \\
1316\end{array}$ & $\begin{array}{l}\text { 2- and 3-methylbutanols } \\
\text { Heptan-2-ol }\end{array}$ & Nd & $\mathrm{Nd}$ & 1.61 & 2.53 \\
\hline 1328 & Hexan-1-ol & $\mathrm{Nd}$ & $\mathrm{Nd}$ & 116.84 & 75.06 \\
\hline 1395 & (Z)-hex-1-en-3-ol & $\mathrm{Nd}$ & $\mathrm{Nd}$ & 10.60 & 6.82 \\
\hline 1440 & Ethyl octanoate & 11.19 & 6,25 & 59.23 & 36.96 \\
\hline 1455 & Oct-1-en-3-ol & $\mathrm{Nd}$ & $\mathrm{Nd}$ & 2.92 & 1.59 \\
\hline 1514 & 2-ethyl-hexan-1-ol & 0.46 & 0.48 & 1.31 & 0.58 \\
\hline 1543 & vitispiranes & $\mathrm{Nd}$ & $\mathrm{Nd}$ & 0.07 & $\mathrm{Nd}$ \\
\hline 1553 & Linalol & 0.45 & 0.31 & 5.36 & 10.12 \\
\hline 1729 & $\alpha$-terpineol & $\mathrm{Nd}$ & $\mathrm{Nd}$ & 10.34 & 3.66 \\
\hline 1780 & Citronellol & $\mathrm{Nd}$ & $\mathrm{Nd}$ & 0.2 & $\mathrm{Nd}$ \\
\hline 1786 & Methyl salicylate & $\mathrm{Nd}$ & $\mathrm{Nd}$ & 58.50 & 77.84 \\
\hline 1862 & Hexanoic acid & 0.59 & 0.51 & 1.29 & 0.84 \\
\hline 1921 & 2-phenylethanol & 403.02 & 185.51 & 522.36 & 255.78 \\
\hline 2024 & $o$-cresol + phenol & $\mathrm{Nd}$ & $\mathrm{Nd}$ & 0.21 & 0.16 \\
\hline 2034 & Pantolactone $+\gamma$-nonalactone & 0.05 & 0.07 & 0.14 & 0.08 \\
\hline 2091 & $m$ - and $p$-cresols & $\mathrm{Nd}$ & $\mathrm{Nd}$ & 0.12 & 0.17 \\
\hline 2127 & p-cymen-7-ol & $\mathrm{Nd}$ & $\mathrm{Nd}$ & 0.15 & 0.06 \\
\hline 2201 & 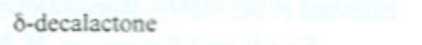 & Nd & $\mathrm{Nd}$ & 0.10 & 0.11 \\
\hline 2215 & hydroxymethylacetophenone & $\mathrm{Nd}$ & $\mathrm{Nd}$ & 0.15 & 5.98 \\
\hline 2218 & 4-vinyl-gaiacol & $\mathrm{Nd}$ & $\mathrm{Nd}$ & 0.95 & $\mathrm{Nd}$ \\
\hline 2266 & 2,6-dimethoxyphenol & $\mathrm{Nd}$ & $\mathrm{Nd}$ & 0.06 & 0.08 \\
\hline 2548 & Methoxyeugenol & 0.01 & 0.08 & 0.29 & 1.86 \\
\hline 2570 & Phenylacetic acid & 0.55 & 0.36 & 0.95 & 0.71 \\
\hline 2645 & Ethyl vanillate & 0.62 & 2.63 & 1.00 & 5.78 \\
\hline 3015 & 4-(p-hydroxy-phenyl)-butan-2-one & 0.38 & 0.11 & 0.81 & 0.25 \\
\hline 3091 & 4-(p-hydroxy-phenyl)-butan-2-ol & 0.28 & 0.08 & 0.79 & 0.36 \\
\hline
\end{tabular}

a RI: Retention Index on DBWAX column; compounds are those listed in table 1. ${ }^{b}$ Estimated concentration, in equivalents of 4-nonanol, used as external standard, per liter of model wine; Nd: non detected. The four samples correspond to extracts of model wines added with glycoconjugates, enzymed with glycosidases or not (DE or D). 
e) Correlations with the data of the sensory analysis

The correlation between the data of the sensory analysis (Ségurel et al., 2009) and that obtained by GC$\mathrm{O}$ was difficult to establish because the $\mathrm{CG}-\mathrm{O}$ resolutive approach did not take into account complex interactions between odorant compounds and between these compounds and their matrix (Aznar et al., 2001; Ferreira et al., 2002; Escudero et al., 2004). Compounds of very different aroma classes can be involved in the expression of one single odour and conversely, one single component can contribute to the expression of different sensory notes, with no obvious link between these notes and the odour of the pure compound. These interactions are particularly important in complex liquids such as wine.

Furthermore the comparison with the wines tasted in the previous work (Ségurel et al., 2009) was difficult to establish because the fermentation-derived esters and other fermentation-derived odorants were present only in the wines and some of them (ethyl esters of branchedchains acids) increased during aging.

\section{CONCLUSION}

The olfactometric analysis of synthetic model wines, enriched with glycosides and aged using model and natural aging, revealed several odorants contributing to their aroma. Moreover, varietal differences in the relative proportions of certain odorants generated from glycosides of both varieties were observed. Although several compounds eluted at the same retention time could be at the origin of some odorant areas, odors perceived by GC-O were tentatively linked to compounds identified by GC-MS. However it would be interesting to perform a bi-dimensional chromatography to confirm this hypothesis.

Correlations with the data of the sensory analysis (Segurel et al., 2010) were difficult to establish, however the differences observed in GC-O of synthetic model wines enriched with glycosides and artificially aged were consistent with those detected by the sensory analysis of the corresponding wines. In both cases, enzyme treatment modified more significantly the aroma profiles of Grenache wines than those of Syrah.

Moreover, for the glycosidic fraction, the model aging, as proposed by Francis et al. (1994), appeared to be a good technic to reproduce a natural aging of several years. The compounds arising during this artificial aging were similar to those naturally obtain after several years.

Acknowledgement :We thank Inter-Rhone for providing grapes, wines, technical and financial support.

\section{LITERATURE CITED}

Abbot N. A., Coombe B. G. and Williams P. J., 1991. The Contribution of Hydrolyzed Flavor Precursors to Quality Differences in Shiraz Juice and Wines: An Investigation by Sensory Descriptive Analysis. Am. J. Enol. Vitic., 42, 167174.

Acree T. E., Barnard J. and Cunnigham D. G., 1984. A procedure for sensory analysis of chromatographic effluents. Food Chem., 14, 273-286.

Aubert C., Ambid C., Baumes R. and Günata Y. Z., 2003. Investigation of bound aroma constituents of yellow-fleshed nectarines (Prunus persica L. Cv. springbright). Changes in bound aroma profile during maturation. J. Agric. Food Chem., 51, 6280-6286.

Aubry V., 1999. Contribution à la connaissance aromatique des vins de Pinot noir par des méthodes instrumentales et sensorielles. phD Thesis, Université de Bourgogne (Dijon), France.

Aznar M., Lopez R., Cacho J. F. and Ferreira V., 2001. Identification and quantification of impact odorants of aged red wines from Rioja. GC-olfactometry, quantitative GC-MS, and odor evaluation of HPLC fractions. J. Agric. Food Chem., 49, 2924-2929.

Bernet C., 2000. Contribution à la connaissance des composés d'arôme clés des vins du cépage Gewürztraminer cultivé en Alsace. phD thesis, Université de Bourgogne (Dijon), France.

Cullere L., Escudero A., Cacho J. F. and Ferreira V., 2004. Gas chromatography-olfactometry and chemical quantitative study of the aroma of six premium quality spanish aged red wines. J. Agric. Food Chem., 52, 1653-1660.

Escudero A. and Etievant P., 1999. Effect of antioxidants on the flavor characteristics in the gas chromatography/olfactometry profiles of champagne extracts. J. Agric. Food Chem., 47, 3303-3308.

Escudero A., Hernandez-Orte P., Cacho J. F. and Ferreira V., 2000. Clues about the role of methional as character impact odorant of some oxdized wines. J. Agric. Food Chem., 48, 42684272.

Escudero A., Gogorza B., Melus M. A., Ortin N., Cacho J. F. and Ferreira V., 2004. Characterization of the aroma of a wine from Maccabeo. Key role played by compounds with low odor activity values. J. Agric. Food Chem., 52, 35163524.

Etiévant P. X., 1991. Wine (483-546). In: Volatile compounds in Foods and Beverages, H. Maarse (Ed). New-York, Basel, Honk-Hong: Dekker, 790 p.

Ferreira V., Lopez R., Escudero A. and Cacho J. F., 1998. The aroma of Grenache red wine : hierarchy and nature of its main odorants. J. Sci. Food Agric., 77, 259-267.

Ferreira V., Ortin N., Escudero A., Lopez R. and Cacho J. F., 2002. Chemical characterization of the aroma of Grenache Rosé wines: aroma extract dilution analysis, quantitative determination and sensory reconstitution studies. J. Agric. Food Chem., 50, 4048-4054.

Francis I. L., Sefton M. A. and Williams P. J., 1994. The sensory effects of pre- or post-fermentation thermal processing on 
Chardonnay and Semillon wines. Am. J. Enol. Vitic., 45, 243-251.

Günata Y. Z., Bayonove C. L., Baumes R. L. \& Cordonnier R. E., 1985. The Aroma of Grapes. II. Localisation and Evolution of Free and Bound Fractions of Some Aroma Components cv Muscat During first Development and Maturation. J. Sci. Food Agric., 36, 857-862.

Kotseridis Y. , 1999. Étude de l'arôme des vins de Merlot et Cabernet-Sauvignon de la région bordelaise. phD Thesis, Université Victor Segalen Bordeaux II, France, 268 pages.

Kotseridis Y. and Baumes R, 2000. Identification of impact odorants in Bordeaux red grape juice, in commercial yeast used for its fermentation and in the produced wine. J. Agric. Food Chem., 48, 400-406.

Lopez R., Ferreira V., Hernandez P. and Cacho J. F., 1999. Identification of impact odorants of young red wines made with Merlot, Cabernet-Sauvignon and Grenache grape varieties: a comparative study. J. Sci. Food Agric., 79, 14611467.

Lopez R., Ezpeleta E., Sanchez I., Cacho J. F. and Ferreira V., 2004. Analysis of the aroma intensities of volatile compounds released from mild acid hydrolysates of odourless precursors extracted from Tempranillo and Grenache grapes using gas chromatography-olfactometry. Food Chem., 88, 95-103.

Marais J., 1983. Terpenes in the aroma of grapes and wines : a review. S. Afr. J. Enol. Vitic., 4, 49-58.

Masson E., Baumes R., Le Guernevé C. and Puech J. L., 2000. Identification of a precursor of $\beta$-methyl- $\gamma$-octalactone on the wood sessile oak (Quercus petraea (Matt.) Liebl.). J. Agric. Food Chem., 48, 4306-4309.

Ormières J. F., Baumes R., Masson G., Lurton, L. Bayonove C. and Razungles A., 1997. Le Potentiel aromatique du Grenache noir : aspects sensoriels (70-75). In : Actes du XXII Congrès Mondial de la Vigne et du Vin, Buenos Aires, Ed. O.I.V., Paris.

Pabst A., Barron D., Etievant P. X. and Schreier P., 1991. Studies on the enzymatic hydrolysis of bound aroma constituents from raspberry fruit pulp. J. Agric. Food Chem., 39, 173 175 .

Pollien P., Ott A., Montognin F., Baumgartner M., Munoz-Box R. and Chaintreau A., 1997. Hyphenated headspace-gas chromatography-sniffing technique: screening of impact odorants and quantitative aromagrams comparisons. J. Agric. Food Chem., 45, 2630-2637.

Sefton M., Francis I.L. and Winterhalter P., 1993. The volatile composition of Chardonnay Juices: a study by flavour precursors analysis. Am. J. Enol. Vitic., 44, 359-370.

Ségurel M. A., 2005. Contribution des précurseurs glycosidiques et du sulfure de diméthyle des baies de Vitis vinifera L. cv. Grenache noir et Syrah à l'arôme des vins de la vallée du Rhône. Thèse de Doctorat, École Nationale Supérieure d'Agronomie de Montpellier.

Ségurel M.A., Baumes R.L., Riou C. and Razungles A.J., 2009. Role of glycosidic aroma precursors on the odorant profiles of Grenache noir and Syrah wines from the Rhone valley.
Part 1: sensory study. J. Int. Sci. Vigne Vin, 43, n4, 199-211.

Strauss C. R., Wilson B., Anderson R. J. and Williams P. J., 1987. Development of precursors of C13-norisoprenoid flavorants in Riesling grapes. Am. J. Enol. Vitic., 38, 23-27.

Thomas-Danguin T., Rouby C., Sicard G., Vigouroux M., Farget V., Jahansson A., Bengtzon A., Hall G., Ormel W., De Graaf C., Rousseau F. and Dumont J.P., 2003. Development of the ETOC: a European test of olfactory capabilities. Rhinology, 41, 142-151.

Ullrich F. and Grosch W., 1987. Identification of most intense volatile flavor compounds formed during autooxydation of linoleic acid. Z Lebensm. Unters. Forsch., 184, 277-282.

Van Ruth S. M., Roozen J. P. and Cozijnsen J. L., 1996. Gas chromatography sniffing port analysis evaluated for aroma release from rehydrated french beans (Phaseolus vulgaris). Food Chem., 56, 343-346.

Van Ruth S.M., 2001. Methods for gas chromatographyolfactometry: a review. Biomolecular Engineering, 17, 121128.

Winterhalter P., Sefton M. A. and Williams P. J., 1990. Volatile C13-norisoprenoid compounds in Riesling wine are generated from multiple precursors. Am. J. Enol. Vitic., 41, 547-558,

Winterhalter P., 1991. 1,1,6-Trimethyl-1,2-dihydronaphtalene (TDN) Formation in Wine. 1. Studies on the Hydrolysis of 2,6,10,10-Tetramethyl-1-oxaspiro[4.5]dec-6-en-2,8-diol Rationalizing the Origin of TDN and Related C13norisoprenoids in Riesling Wine. J. Agric. Food Chem., 39, 1825-1829.

Winterhalter P., Lutz, A. and Schreier P., 1991. Isolation of a glucosidic precursor of isomeric marmelo lactones from quince fruit. Tetrahedron Lett., 32, 3669-3670.

Winterhalter P., 1992. Oxygenated C13-norioprenoids. Important flavor precursor (98-115). In thermal and enzymatic conversions of precursors to flavor compounds. R. Teranishi, G. Takeoka and M. Günther, Eds American Chemical Society, Washington, $268 \mathrm{p}$.

Winterhalter P., 1993. The generation of C13-norisoprenoids volatiles in Riesling wine (65-73). In : Connaissance aromatique des cépages et qualité des vins. J. Crouzet, C. Flanzy, C. Martin and J. C. Sapis (Eds). R.F.OE. Montpellier $460 \mathrm{p}$.

Winterhalter P. and Skouroumounis G.K., 1997. Glycoconjugated aroma compounds: occurrence, role and biotechnological transformation. Advances in Biochemical Engineering/ Biotechnology, 55, 73-105.

Wirth J., Guo W., Baumes R. and Günata Y. Z., 2001. Volatile compounds released by enzymatic hydrolysis of glycoconjugates of leaves and grape berries from Vitis vinifera Muscat of Alexandria and Shiraz cultivars. J. Agric. Food Chem, 49, 2917-2923.

Wu P., Kuo M. C., Hartman T. G., Rosen R. T. and Ho C. T., 1991. Free and glycosidically bound aroma compounds in pineapple (Ananas comosus L. Merr.). J. Agric. Food Chem., 39, 170-172. 